\title{
Rural Livelihoods and Burning Practices in Savanna Landscapes of Nusa Tenggara Timur, Eastern Indonesia
}

\author{
Jeremy Russell-Smith • Siliwoloe Djoeroemana • \\ Josef Maan • Petrus Pandanga
}

Published online: 1 December 2006

(C) Springer Science + Business Media, LLC 2006

\begin{abstract}
Substantial attention has been given in recent years to forest and peatland degradation, transboundary haze, and biodiversity and economic impacts associated with major fire events in perhumid western Indonesia. Conversely, little information is available concerning underpinning conditions associated with burning practices and resultant fire patterns in other parts of the Indonesian archipelago, especially in markedly seasonally dry regions. As part of a broader study examining the patterning and drivers of burning in the monsoonal province of Nusa Tenggara Timur (NTT), the paper explores cultural, socioeconomic, biophysical, and, in discussion, political dimensions associated with landscapescale patterns of burning at each of two village locations on the islands of Sumba and Flores. Assembled data illustrate that: (1) study villages are reliant on a range of subsistence agricultural activities, particularly annual food crops, livestock (especially pigs), and forest products; (2) while villages encompass mostly extensive areas of grassland savanna, proportionately most income/products are derived from limited areas of arable agricultural and very diminished forested lands; (3) despite this, considerable economic
\end{abstract}

J. Russell-Smith $(\bowtie)$

Tropical Savannas Management Cooperative Research Centre,

Darwin, Northern Territory, Australia

e-mail: jeremy.russell-smith@nt.gov.au

J. Russell-Smith

Bushfires Council of the Northern Territory,

Winnellie, Northern Territory, Australia

S. Djoeroemana $\cdot$ P. Pandanga

Wira Wacana School of Economics,

Waingapu, Nusa Tenggara Timur, Indonesia

J. Maan

Yayasan Mira Tani Mandiri,

Bajawa, Nusa Tenggara Timur, Indonesia potential exists for developing certain tree products especially in agro-forestry settings, and more intensive livestock management; (4) these patterns are representative generally of surrounding regional agricultural landscapes. While burning is used as an essential agricultural management tool in defined seasonal contexts in all study villages, the reality is that today much burning is unmanaged and uncontrolled, with attendant significant economic impacts. As for western Indonesia, underlying drivers of such behavior are multiple and complex, but pointedly include: rapid societal change; conflicts within and between villages, and between villages and regulatory authorities (especially the Forestry Department), over access to land and resources; and continued nonrecognition in national and provincial fire policy frameworks of the practical necessity for using fire (wisely and safely) in many agricultural contexts. It is axiomatic that, without effective fire management and a supportive policy environment, sustainable livelihoods development will continue to be elusive in fire-prone savanna landscapes of eastern Indonesia.

Key words Fires · burning · livelihoods · agriculture . savanna $\cdot$ forest $\cdot$ eastern Indonesia $\cdot$ policy

\section{Introduction}

In recent years the underlying causes of peatland degradation, transboundary haze, biodiversity and economic impacts of fire conflagrations in western Indonesia associated with major El Nino Southern Oscillation (ENSO) events have received considerable attention (Colfer, 2002; Page et al., 2002; Tacconi, 2003; Mudiyarso et al., 2004; Dennis et al., 2005). By contrast, not so well documented are the underpinning conditions associated with burning 


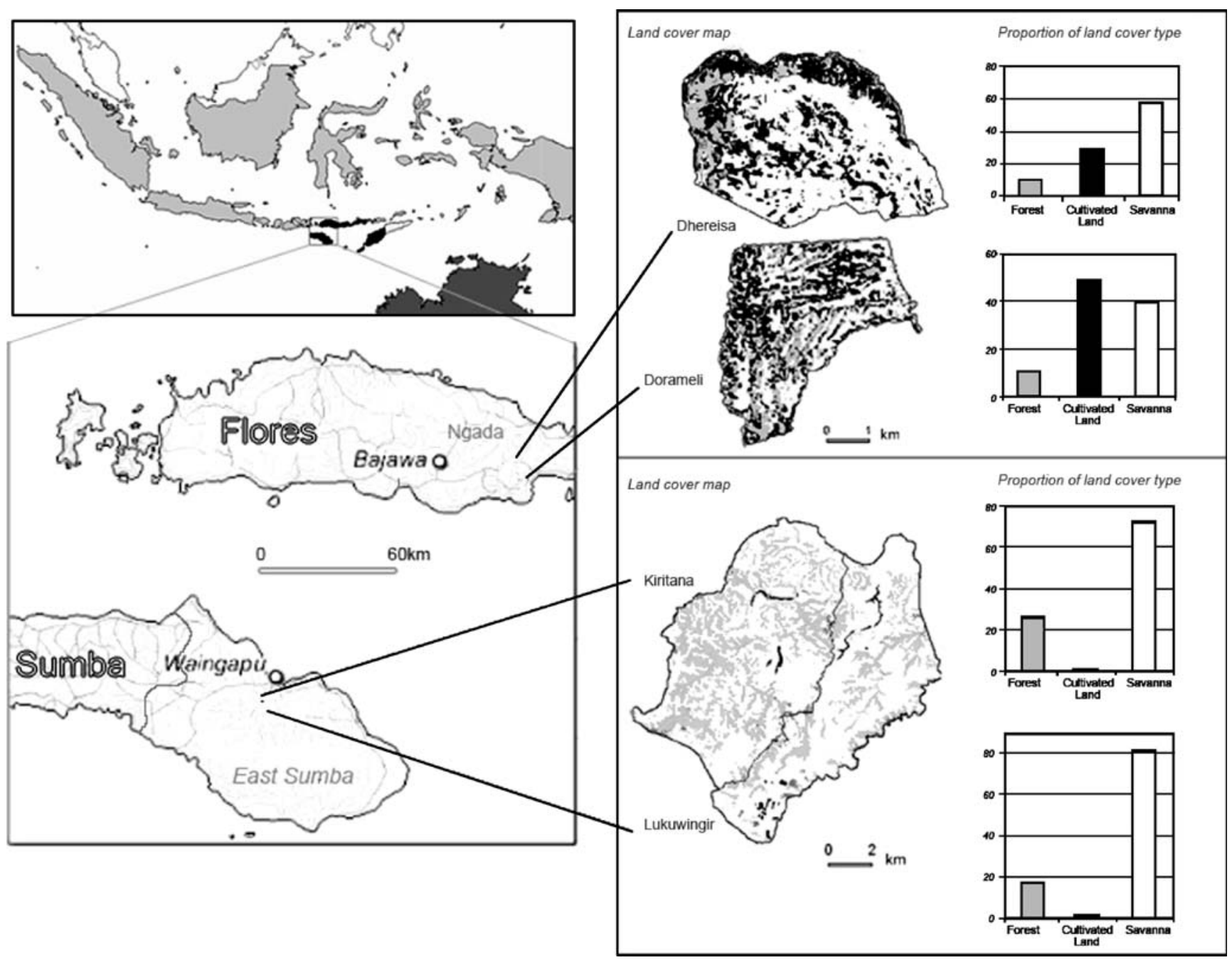

Fig. 1 Study site locations, and land cover types at respective study villages.

practices and resultant fire patterns in other parts of the Indonesian archipelago, especially in markedly seasonally dry (monsoonal) regions (Dennis, 1999).

A salient example is provided by the Province of Nusa Tenggara Timur (NTT), which includes the major islands of Flores, Sumba, and the western half of Timor, home to some 4.5 million people. Economically, NTT is among the poorest of Indonesia's Provinces (Biro Pusat Statistik, 2004), with heavy reliance on subsistence dryland agriculture (Barlow et al., 1990; Djoeroemana et al., 2000). Fire is an integral component of regional traditional/cultural and contemporary agricultural management systems (Fox, 1977; Ataupah, 2000; Therik, 2000) but, today, uncontrolled fire practices can have very significant impacts on people's livelihoods - destroying crops, pasture and buildings, impacting on forest resources, and exacerbating soil erosion and resultant downstream/coastal sedimentation (Bamaulin, 2000; Gadas, 2000; McWilliam, 2000; Mudita, 2000). Despite such generalizations, the significance of relationships at the village scale between rural livelihoods, available resources, burning practices, and broader policy settings are neither documented nor well understood. As with the complex array of underlying causes contributory to contemporary fire management issues in western Indonesia described by Dennis et al. (2005), it can be expected that underlying causes of fire management problems in strongly seasonal settings are likely to differ substantially in and between different regions.

Over longer time frames fire in eastern Indonesia is considered a key agent in the conversion of once widespread regional tropical and monsoon forests to savanna (Monk et al., 1997). Kurniawan and Tacconi (2005) estimate that forest cover in NTT currently comprises just $9.6 \%$ of the land area. In a complementary study to that presented here, Fisher et al. (2006), using remote sensing and geographic information system (GIS) techniques, characterize the seasonal patterning of burning from eastern Sumba and central Flores in 2003 and 2004, as: (1) fires burnt an annual average of $29 \%$ of eastern Sumba (comprising mostly grassland savanna), and $11 \%$ of central Flores (with large forested areas); (2) most fire extent 
occurred in savanna grassland areas, and significantly also in cultivated lands and small remnant patches of forest; (3) most fire activity occurred under harsh, late dry season conditions; and (4) while the great majority of individual fires were less than 5 ha, some late dry season fires were hundreds of hectares in extent.

With reference to the same eastern Sumba and central Flores study locales addressed by Fisher et al. (2006), this paper explores cultural, socioeconomic, biophysical, and, in discussion, political dimensions underpinning landscapescale patterns of burning in semiarid eastern Indonesia settings. In so doing, we assess recent propositions by Dove (2004) and Tacconi and Ruchiat (2006) that, given Westerncentric value systems, forest livelihood resources in Indonesia (and elsewhere) are typically overemphasised vis-à-vis 'degraded grassland production systems.' An important corollary is that, should this in fact be the case, then increased endeavor needs to be given to fostering grassland-based economic activities (e.g., enhancing Imperata- or livestockbased enterprises) rather than promotion of perhaps more fashionable agro-forestry or forest rehabilitation programs. A more encompassing view might be that, depending on the specific circumstances and conditions confronting rural communities, all livelihood options have their place.

\section{Study Sites}

The study focuses on four villages on the islands of Sumba and Flores in the monsoonal, archipelagic Indonesian Province of Nusa Tenggara Timur (NTT). Following consultation with local government and community (i.e., non-government organization) partners, these four villages were selected on the bases that (a) they were known to experience significant fire management problems, (b) they were likely to be socioculturally and economically representative of their broader administrative Districts (Regencies or kabupaten), (c) they were within relatively close proximity to district capital cities, and thus would serve as effective demonstration sites, (d) respective communities readily consented to being included. The broad aims of the study (including matters reported by Fisher et al., 2006) were to (a) develop and demonstrate the utility of coordinated fire management both within and between village communities, and thereby enhance community livelihoods, and (b) build the capacity and confidence of local government in support of community-based fire management initiatives in the face of national and provincial regulations prohibiting all lighting of fires (refer Discussion).

On Sumba, studies were conducted primarily in two contiguous villages, Lukuwinggir and Kiritana, near Waingapu, the capital city of the $7,000 \mathrm{~km}^{2}$ East Sumba Regency (Fig. 1). These villages respectively comprise 51.8 and $63.7 \mathrm{~km}^{2}$ planar land area, and support populations of around 530 and 1,500 people. Mean average rainfall is over $800 \mathrm{~mm}$ p.a., occurring mostly between November and April. Elevation ranges between near sea-level to over $500 \mathrm{~m}$. The topography is very rugged, dominated by deeply incised, erodible limestone which supports open savanna grasslands and only light grazing (cattle, horses), and fertile, although mostly seasonally arid, alluvial/colluvial valleys which are cultivated for a variety of subsistence crops (corn, vegetables, some rice; Fig. 2a). While small in area, patches of remnant forest contribute significantly to household economies (see "Results"). The congruence of a long dry season, shallow, excessively drained soils, and abundant grassy fuels, provides for an extensive burning period.

In central Flores, two nearby village study areas, Dhereisa and Dorameli, were located in the 3,000 $\mathrm{km}^{2}$ Ngada Regency (Fig. 1): Dhereisa covers $17 \mathrm{~km}^{2}$ and includes 800 people; Dorameli covers $10.3 \mathrm{~km}^{2}$ and supports 900 people. Mean annual rainfall is likely to be
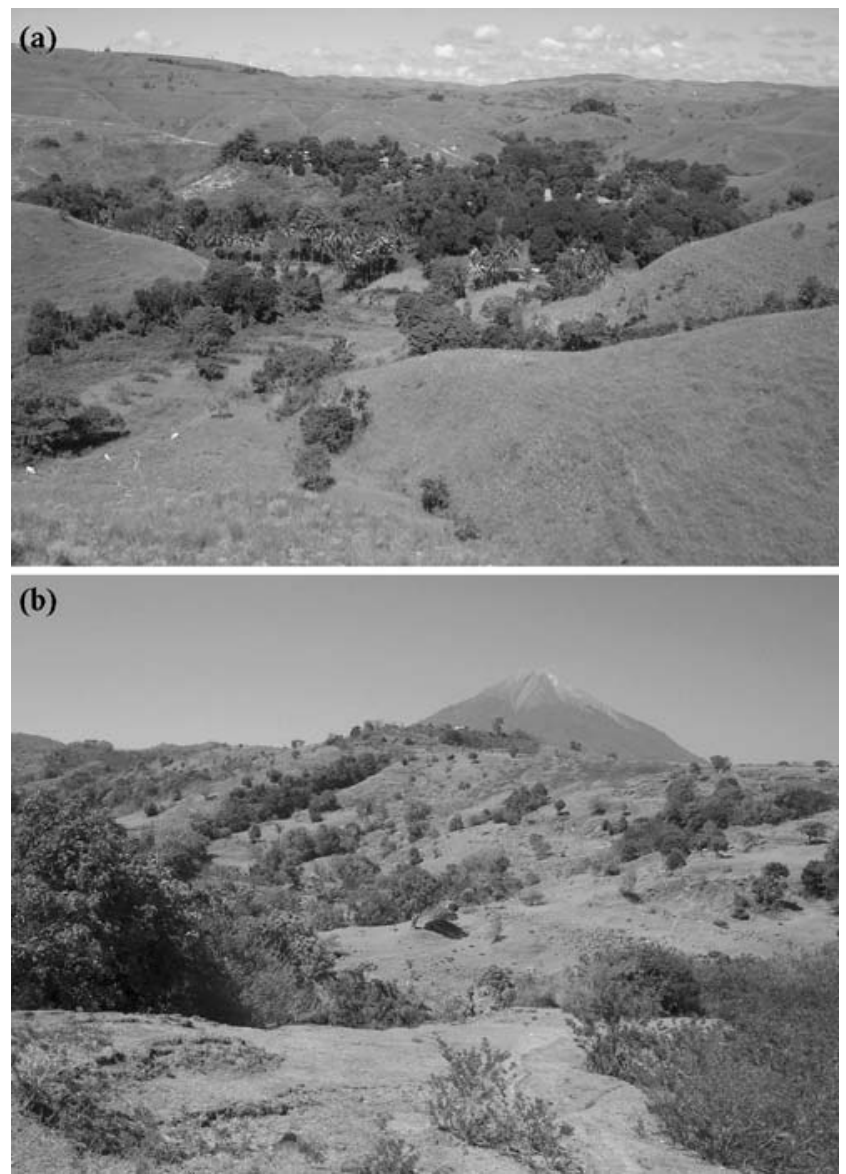

Fig. 2 a Village site at Lukuwinggir (East Sumba) illustrating gardens (kebun) in valley bottoms, surrounded by unburnt grassland savanna (early in the dry season) with scattered trees, and some remnant forest in gullies; b view from Dorameli (Ngada, Flores) to Gunung Elbelobo, illustrating matrix of remnant forest in grassland savanna. Note that scattered, fire-suppressed woody plants occur in grasslands at both sites. 
Table I Population and Income Summary for East Sumba and Ngada Regencies, and Individual Study Villages

\begin{tabular}{|c|c|c|c|c|}
\hline & \multicolumn{2}{|l|}{ East Sumba } & \multicolumn{2}{|l|}{ Ngada (Flores) } \\
\hline \multicolumn{5}{|l|}{ Regency } \\
\hline Population & $193,900^{\mathrm{a}}$ & & $231,300^{\mathrm{b}}$ & \\
\hline Area $\left(\mathrm{km}^{2}\right)$ & $7,000^{\mathrm{a}}$ & & $3,038^{\mathrm{b}}$ & \\
\hline Population density $\left(\mathrm{km}^{-2}\right)$ & $27.6^{\mathrm{a}}$ & & $76.1^{\mathrm{b}}$ & \\
\hline Population growth (\% p.a.) & $2.07^{\mathrm{a}}$ & & $1.26^{\mathrm{b}}$ & \\
\hline No. households & $39,200^{\mathrm{a}}$ & & $37,992^{\mathrm{b}}$ & \\
\hline Average no. persons per household & $4.95^{\mathrm{a}}$ & & $6.1^{\mathrm{b}}$ & \\
\hline Income per capita ${ }^{c}$ & $\operatorname{Rp} 840,197^{\mathrm{a}}$ & & $\mathrm{Rp} 2,173,000^{\mathrm{b}}$ & \\
\hline Village study sites & Kiritana & Lukuwinggir & Dhereisa & Dorameli \\
\hline Population & $1,407^{\mathrm{d}}$ & $531^{\mathrm{d}}$ & $791^{\mathrm{f}}$ & $898^{\mathrm{f}}$ \\
\hline Area $\left(\mathrm{km}^{2}\right)$ & 33.5 & 53 & 17.2 & 15 \\
\hline Population density $\left(\mathrm{km}^{-2}\right)$ & 42 & 10 & 46 & 60 \\
\hline Population growth (\% p.a.) & not available & not available & not available & not available \\
\hline No. households & $310^{\mathrm{d}}$ & $128^{\mathrm{d}}$ & $140^{\mathrm{f}}$ & $142^{\mathrm{f}}$ \\
\hline Average no. persons per household & 4.5 & 4.1 & 6 & 7 \\
\hline Gross Household Product per capita ${ }^{c}$ & $\operatorname{Rp} 756,000^{\mathrm{e}}$ & $\operatorname{Rp} 812,000^{\mathrm{e}}$ & $\mathrm{Rp} 1,836,000^{\mathrm{g}}$ & $\mathrm{Rp} 2,836,000^{\mathrm{g}}$ \\
\hline
\end{tabular}

${ }^{a}$ Source: population estimate 2002; population growth 1980-2000 (Biro Pusat Statistik, 2003a)

${ }^{\mathrm{b}}$ Source: population estimate 2002; population growth 1980-2000 (Biro Pusat Statistik, 2003b)

${ }^{c}$ Exchange rate, April 2005: US\$1 $=$ Rp9,500

${ }^{\mathrm{d}}$ Source: estimate for 2002 (Biro Pusat Statistik, 2003c)

'Source: data collected 2002-2003 (ACIAR, 2004a): does not include income derived from home industries (e.g., weaving), and 'other' (e.g., official's salaries)

${ }^{\mathrm{f}}$ Source: estimate for 2002 (Biro Pusat Statistik, 2003d)

${ }^{g}$ Source: data collected 2002-2003 (ACIAR, 2004b)

around $1,400 \mathrm{~mm}$ but is generally seasonally distributed as for East Sumba study sites (Fisher et al., 2006). Elevation is generally between $400-600 \mathrm{~m}$. Topography is undulating to steep, comprising rich volcanic soils derived from the nearby active Gunung Elbelobo (2,124 m; Fig. 2b). Vegetation cover and agricultural activities are similar to those in East Sumba although weaving of textiles and production of palm toddy (from Arenga pinnata) contribute significantly to peoples' livelihoods in Dhereisa and Dorameli respectively (see "Results").

Village societies both at East Sumba and Ngada study sites are strongly patriarchal, and today land ownership is community-based, with a small degree of private ownership at Dorameli, Ngada. Importantly, while the geographical extent of all study villages considered here is recognized administratively (i.e., by respective local government authorities), at Lukuwinggir at least there is considerable intracommunity conflict concerning land ownership. The generality of such issues, as well as land tenure conflicts concerning the ownership of, and access to, forest resources, are considered more fully in discussion.

Significant cultural changes have been occurring in both study site locations over recent decades. At East Sumba sites, such changes have been most pronounced since the early 1970s with the rapid replacement of the traditional three-tiered social hierarchy (nobility—maramba; middle class - kabihu; servant class - ata), with a more egalitarian, classless society. Decisions affecting land and its usage, however, are still referred to the most senior male maramba, and contemporary political appointments (e.g., the head of the village - kepala desa) come only from that class. Family (including marriage) and economic issues
Table II Main Categories of Livelihood Activities, for Both Men and Women, at Individual Study Villages

\footnotetext{
${ }^{\text {a }}$ Source: estimate for 2002 , Biro Pusat Statistik (2003c)

${ }^{\mathrm{b}}$ Source: estimate for 2002, Biro Pusat Statistik (2003d)
}

\begin{tabular}{|c|c|c|c|c|}
\hline \multirow[t]{2}{*}{ Livelihood } & \multicolumn{2}{|c|}{ East Sumba ${ }^{a}$} & \multicolumn{2}{|c|}{ Ngada (Flores) ${ }^{\mathrm{b}}$} \\
\hline & Kiritana & Lukuwinggir & Dhereisa & Dorameli \\
\hline Mixed farmer (food crops and livestock) & 638 & 249 & 610 & 988 \\
\hline Farm labourer & 7 & 2 & - & - \\
\hline Trader & 12 & 2 & 25 & 34 \\
\hline Home industry (e.g. weaving) & 43 & 8 & 342 & 306 \\
\hline Construction labourer & 14 & 2 & 52 & 30 \\
\hline Other (e.g. village officials, teachers) & 12 & 8 & 9 & 5 \\
\hline
\end{tabular}


Table III Average Gross Household Product for East Sumba Study Villages, 2002

\begin{tabular}{|c|c|c|c|c|}
\hline \multirow[t]{4}{*}{ Economic activity } & \multicolumn{4}{|c|}{ East Sumba } \\
\hline & \multirow{2}{*}{\multicolumn{2}{|c|}{$\begin{array}{l}\text { Kiritana }(n=40) \\
\text { Average gross } \\
\text { household product }\end{array}$}} & \multirow{2}{*}{\multicolumn{2}{|c|}{$\begin{array}{l}\text { Lukuwinggir }(n=40) \\
\text { average gross } \\
\text { household product }\end{array}$}} \\
\hline & & & & \\
\hline & $\begin{array}{l}\mathrm{Rp} \\
(\times 1,000)\end{array}$ & Percent & $\begin{array}{l}\mathrm{Rp} \\
(\times 1,000)\end{array}$ & Percent \\
\hline $\begin{array}{l}\text { Foodcrops and } \\
\text { vegetables }\end{array}$ & 1,788 & 52.5 & 651 & 19 \\
\hline Corn & & $(30)$ & & $(45)$ \\
\hline Chillies & & (25) & & (19) \\
\hline Tomatoes & & (23) & & (17) \\
\hline Perennial crops & 210 & 6 & 76 & 2 \\
\hline Livestock & 305 & 9 & 1,308 & 39 \\
\hline Pigs & & (47) & & (39) \\
\hline Horses & & (41) & & (30) \\
\hline Cattle & & - & & (13) \\
\hline Buffalo & & - & & (8) \\
\hline Poultry & & (12) & & (7) \\
\hline Forest products & 1,006 & 29.5 & 1,072 & 33 \\
\hline $\begin{array}{l}\text { construction } \\
\text { timber }\end{array}$ & & (84) & & (72) \\
\hline $\begin{array}{l}\text { Kutu lak } \\
\text { (varnish) }\end{array}$ & & (1) & & (15) \\
\hline Bamboo & & (10) & & (3) \\
\hline $\begin{array}{l}\text { fencing } \\
\text { materials }\end{array}$ & & (6) & & (6) \\
\hline forest tubers & & - & & (4) \\
\hline $\begin{array}{l}\text { Grassland/ } \\
\text { savanna products }\end{array}$ & 93 & 3 & 223 & 7 \\
\hline Imperata thatch & & $(100)$ & & $(100)$ \\
\hline Home industries & N/A & & N/A & \\
\hline Other & N/A & & N/A & \\
\hline
\end{tabular}

Numbers in parentheses denote proportion of contribution to major economic activity.

N/A Not available

typically are dealt with by male heads of households. At Ngada sites, similar pronounced cultural change has been occurring since at least the 1940s, and, as for East Sumba sites, male clan heads (mosalaki) still retain authority for land use matters. Societal changes at the study sites reflect broadly the nature and rates of change occurring in surrounding communities, with the exception that in East Sumba village societies more distant from Waingapu tend to retain more traditional social structures.

\section{Materials and Methods}

Data presented here were assembled over 3 years, 20022004, as part of project activities undertaken both in East Sumba and Ngada study villages, as follows.
Economic Data

Information at kabupaten and kecamatan (subdistrict) scales concerning population and household numbers, population growth (where available), livelihood categories, and average income estimates, were derived from recent national statistical sources as given in Results. At the village scale, using standard Participatory Rural Appraisal (PRA) techniques (e.g., Cunningham, 2002), information concerning the economic contributions of different livelihood activities was derived from individual interviews (based on prepared questionnaires) with project Focus Group Discussion (FGD) members undertaken in 20022003. The PRA process specifically sought responses in relation to contemporary, as well as recent (within living memory) time periods - the latter as defined by respective FGDs. Such information was used for tracking changes concerning (a) the availability, utilization, and relative value of resources, (b) various social, cultural, and demographic phenomena, and (c) burning practices (ACIAR, 2004a,b).

At each village, FGD members were selected by community leaders from high, medium, and low economic status households. Respective FGDs comprised more-or-less equal representation of men and women; only one member per household was included. In East Sumba, FGDs comprised 40 members from each village. In Ngada, there were two FGDs per village with a total of 143 members; however, household economic information was derived from only 27 members in Dhereisa, and 26 in Doromeli. Economic information derived from these interviews is summarized here as the Gross Household Product (GHP), combining annual income derived from products sold with the estimated value of products used (e.g., vegetables derived from home gardens, domestic livestock consumption, use of firewood in cooking). The economic value of used products was the current local market price at the time of the survey.

\section{Burning Practices}

Information concerning prescribed contemporary and recent burning practices, and the incidence of fires generally, was derived from discussions with respective FGDs, augmented with field observations over the 3 year study period. These data were used to assemble seasonal burning calendars, and associated commentaries including recent changes in practices, for respective villages.

\section{Forest Resource Inventory}

On the bases of (1) detailed land cover mapping undertaken at all four study villages (Fisher et al., 2006) which indicated that forested lands comprise around $20 \%$ of land surface area at East Sumba study sites, and much less than 
this at Ngada sites (Fig. 1), (2) economic assessments which indicate that disproportionately high income contributions are derived from forest resources (refer "Results"), and (3) fire mapping (Fisher et al., 2006) and anecdotal FGD information reported here which together indicate that forested areas are under significant fire impact, forest resource inventories were undertaken at Doromeli in 2003, and Lukuwinggir in 2004, to assess their status and condition. The applied forest inventory methodology involved:

Definition of Economically Important Species This was undertaken as a participatory community exercise, including FGD members. Participants were asked to compile a list, firstly of the 30 most economically important ('Priority') species, along with their usages, and broad habitat relations (e.g., forest, savanna, or kebun - garden). At Lukuwinggir, given the involvement of two sub-villages, a combined list of 36 Priority species was agreed upon. After these initial

Table IV Average Gross Household Product for Ngada (Flores) Study Villages, 2002

\begin{tabular}{|c|c|c|c|c|}
\hline \multirow[t]{4}{*}{ Economic activity } & \multicolumn{4}{|c|}{ Ngada (Flores) } \\
\hline & \multirow{2}{*}{\multicolumn{2}{|c|}{$\begin{array}{l}\text { Dorameli }(n=27) \\
\text { Average gross } \\
\text { household product }\end{array}$}} & \multirow{2}{*}{\multicolumn{2}{|c|}{$\begin{array}{l}\text { Dhereisa }(n=26) \\
\text { average gross } \\
\text { household product }\end{array}$}} \\
\hline & & & & \\
\hline & $\begin{array}{l}\mathrm{Rp} \\
(\times 1,000)\end{array}$ & Percent & $\begin{array}{l}\mathrm{Rp} \\
(\times 1,000)\end{array}$ & Percent \\
\hline $\begin{array}{l}\text { Foodcrops and } \\
\text { vegetables }\end{array}$ & 5,731 & 29 & 1,826 & 17 \\
\hline Rice & & $(27)$ & & (15) \\
\hline Corn & & (23) & & $(54)$ \\
\hline Peanuts & & $(30)$ & & $(10)$ \\
\hline Cassava & & $(10)$ & & $(11)$ \\
\hline Perennial crops & 1,076 & 5 & 335 & 3 \\
\hline $\begin{array}{l}\text { Livestock } \\
\text { Pigs }\end{array}$ & 5,713 & $\begin{array}{l}29 \\
(39)\end{array}$ & 1,581 & $\begin{array}{l}14 \\
(49)\end{array}$ \\
\hline Cattle & & (27) & & (37) \\
\hline Horses & & (15) & & (4) \\
\hline Buffalo & & $(10)$ & & - \\
\hline Poultry & & $(8)$ & & $(6)$ \\
\hline Forest products & 4,168 & 21 & 3,201 & 29 \\
\hline Construction timber & & $(40)$ & & $(58)$ \\
\hline Palm toddy & & $(21)$ & & - \\
\hline Wild animal products & & (9) & & (11) \\
\hline Firewood & & (5) & & (9) \\
\hline $\begin{array}{l}\text { Grassland/savanna } \\
\text { products }\end{array}$ & 1,958 & 10 & 1,174 & 11 \\
\hline Imperata thatch & & (19) & & (32) \\
\hline Home industries & 994 & 5 & 2,098 & 19 \\
\hline Other & 215 & 1 & 799 & 7 \\
\hline
\end{tabular}

Numbers in parentheses denote proportion of contribution to major economic activity. lists were compiled, participants were asked to nominate around ten or so 'High Priority' species.

Survey of Priority Species Surveys were undertaken over 10 days at both villages, involving teams of villagers, botanists, foresters, and database experts. Using available land cover maps depicting the distribution of forest vegetation in respective villages, villagers were asked to nominate locales which they considered contained concentrations of Priority species. Additional locations were selected at random to assess selection bias. As many locations were sampled as time would allow.

At each predetermined location, plots of $50 \times 20 \mathrm{~m}$ dimension were established, with the long axis of the plot positioned such that environmental variability was minimized (e.g., running along streams, contours). Collected data pertinent to this paper include: (1) counts of individuals of Priority species in each of three size classes $(<2 \mathrm{~m}$ tall; $2 \mathrm{~m}-$ $10 \mathrm{~cm}$ Diameter at Breast Height [DBH]; $>10 \mathrm{~cm}$ DBH); measurement of DBH for all stems $>10 \mathrm{~cm} \mathrm{DBH}$; measured heights of the tallest five stems, using a hand-held clinometer; canopy cover, recorded systematically at five $1 \mathrm{~m}^{2}$ locations per plot, where $0=$ no canopy; $1=$ partial canopy; $2=>50 \%$ canopy. A Canopy Cover Index was calculated from canopy cover data, comprising the sum of individual counts divided by 10 .

Priority species were recorded in the field using local names; subsequently, specimens of all scientifically unidentified species were identified at the national herbarium, the Herbarium Bogoriense.

\section{Results \\ Population, Economics, Livelihoods}

At the District scale, population densities, the number of people per household, and income per capita are shown to be substantially less in East Sumba than central Flores (Table I). Similar trends are evident for respective village study sites (Table I), indicating that these may be considered representative generally of their wider Regency communities. Given, however, that economic data for study villages are expressed in terms of GHP, it follows that study villages represent situations of lower economic status relative to their respective Regencies, which include major urban centres such as Bajawa (Ngada) and Waingapu (East Sumba). Overall, even in a national Indonesian context (Biro Pusat Statistik, 2004), these rural communities are shown to be economically amongst the very poor.

Most people at all four study villages are reliant on mixed farming livelihood activities, although weaving of 
Table V Seasonal Patterning of Prescribed Burning in the Four Study Villages

\begin{tabular}{lllllllllllllll}
\hline Burning activities & \multicolumn{1}{l}{ Month } & \multicolumn{1}{l}{1} & & & & & & & & \\
\cline { 2 - 9 } & & J & F & M & A & M & J & J & A & S & O & N & D \\
\hline
\end{tabular}

Ngada, Flores

(a) Dorameli

Burn harvest residue

Burn garden plots in preparation for next wet season

Burn to open new areas for garden plots

Burn to encourage grass regrowth for cattle and horses

Burning for hunting purposes

(b) Dhereisa

Burn harvest residue

Burn garden plots in preparation for next wet season

Burn to open new areas for garden plots $\quad \mathrm{X} \quad \mathrm{X}$

Burn to encourage grass regrowth for cattle and horses

Burning for hunting purposes

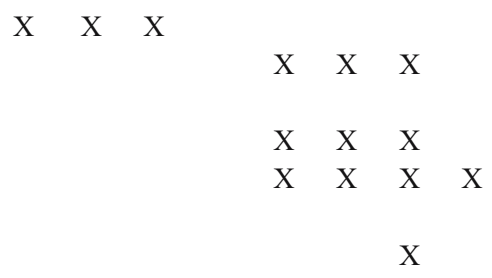

X $\quad X \quad X$

$$
\begin{array}{llll}
X & X & X & \\
& & & \\
X & X & X & \\
X & X & X & X
\end{array}
$$

$$
\mathrm{X}
$$

East Sumba
(a) Kiritana
Burn harvest residue
Burn to clear garden plots in floodplain areas in preparation for dry season planting
Burn garden plots in preparation for next wet season
Burn to open new areas for garden plots Burn to encourage grass regrowth for cattle and horses
Burning for hunting purposes
Burning as part of yam harvesting
Burning for locust management
(b) Lukuwinggir
Burn harvest residue
Burn garden plots in preparation for next wet season
Burn to open new areas for garden plots
Burn to encourage grass regrowth for cattle and horses
Burning for hunting purposes
Burning as part of yam harvesting
Burning for locust management

textiles is a major secondary activity in Ngada (Table II). The relative contributions of different livelihood activities to the calculation of GHP indicate that different activities assume greater prominence in respective villages (Tables III and IV). In East Sumba (Table III), for example, foodcrops and vegetables grown on the fertile river flats of the Sungai Kambaniru at Kiritana contribute over half of GHP, with forest products contributing a third. At Lukuwinggir, livestock and forest products contribute most to GHP. While the contributions of 'Home industries' and 'Other' categories are not accounted for East Sumba study villages, these are unlikely to be a major component of GHP given relatively minor involvement with these livelihood activities, especially at Lukuwinggir (Table II). Of special note at all four study sites is the predominance of construction timber and pigs in forest products and livestock categories, respectively (Tables III and IV). 
Table VI Comparison Between Sampled Vegetation Attributes from Randomly and Community-Based Selected Plots, each of $50 \times 20 \mathrm{~m}$ Dimension

\begin{tabular}{|c|c|c|}
\hline \multirow[t]{2}{*}{ Attribute } & \multicolumn{2}{|c|}{ Plot selection } \\
\hline & Random & $\begin{array}{l}\text { Local } \\
\text { community }\end{array}$ \\
\hline \multicolumn{3}{|l|}{ (a) Lukuwinggir } \\
\hline Number of plots & 19 & 21 \\
\hline Mean Canopy Cover Index & 0.65 & 0.65 \\
\hline Mean canopy height (m) & 18.7 & 19.7 \\
\hline Mean basal area $\left(\mathrm{m}^{2} \mathrm{ha}^{-1}\right)$ & 15.5 & 22.5 \\
\hline \multicolumn{3}{|l|}{ Mean stem density (per 0.1 ha) } \\
\hline Stems $10-30 \mathrm{~cm} \mathrm{DBH}$ & 29.8 & 24.8 \\
\hline Stems $>30 \mathrm{~cm} \mathrm{DBH}$ & 5.1 & 6.7 \\
\hline Mean number of Priority species per plot & 13.2 & 13.5 \\
\hline $\begin{array}{l}\text { Mean stem density }(>10 \mathrm{~cm} \mathrm{DBH}) \text { of } \\
\text { Priority species per plot }\end{array}$ & 19.9 & 20.5 \\
\hline \multicolumn{3}{|l|}{ (b) Dorameli } \\
\hline Number of plots & 26 & 10 \\
\hline Mean Canopy Cover Index & 0.45 & 0.45 \\
\hline Mean canopy height (m) & 20.1 & 21.3 \\
\hline Mean basal area $\left(\mathrm{m}^{2} \mathrm{ha}^{-1}\right)$ & 22.7 & 21.8 \\
\hline \multicolumn{3}{|l|}{ Mean stem density (per 0.1 ha) } \\
\hline Stems $10-30 \mathrm{~cm} \mathrm{DBH}$ & 16.7 & 14.6 \\
\hline Stems $>30 \mathrm{~cm} \mathrm{DBH}$ & 20.3 & 21.1 \\
\hline Mean number of Priority species per plot & 11 & 11 \\
\hline $\begin{array}{l}\text { Mean stem density }(>10 \mathrm{~cm} \mathrm{DBH}) \text { of } \\
\text { Priority species per plot }\end{array}$ & 27.1 & 28.6 \\
\hline
\end{tabular}

\section{Prescribed Burning}

Fire is used as an essential agricultural management tool in all study villages. However, there are both substantial similarities and differences in prescribed burning activities and their timing, as undertaken in East Sumba and Ngada study sites (Table V). In both locations fire is used restrictively to clear and prepare old and new garden plots in readiness for planting in the forthcoming wet season, and extensively as part of broader-scale hunting activities (especially for wild pigs and rusa deer), and for savanna pasture management purposes (especially to encourage grass regrowth for cattle, horses etc.). Restrictive burning for garden preparation occurs earlier in the year in Ngada sites, such that these burning activities are completed by end of August; by contrast, preparatory burning at East Sumba sites anticipates the new wet season rains. Extensive burning for pasture management purposes occurs similarly in the latter half of the dry season (although starts and ends earlier in Ngada), whereas burning for hunting purposes occurs over a substantially longer dry season period at East Sumba sites. In addition to these activities, at East Sumba study sites prescribed burning is undertaken also as a means for (1) at any time of the year when feasible to burn, local control of locust infestations which otherwise have the potential to decimate food crops, (2) in the months leading up to start of the wet season, to facilitate location and harvesting of edible forest yams.

Based on FGD discussions, it is apparent that, while fire management activities have both traditionally and up until very recent times been the responsibility of individual households, significant changes in burning practices have occurred within recent decades. For example, at both Ngada and especially East Sumba sites, many participants commented that former strict restrictive fire management practices around kebun (in both open, cultivated sites in fertile, relatively well-watered valley bottoms, and forested areas) today are frequently not observed. This reflects the general view that, while extensive and intensive burning has "always" been practised, much burning today occurs in an unstructured fashion as a result of ignorance, rapidly changing social structures and demographics, and growing land tenure conflicts (ACIAR, 2004a,b).

\section{Forest Resource Inventory}

Land cover mapping for Lukuwinggir and Dorameli indicates that 873 ha and 633 ha, respectively, support either dense or regenerating forest types (Fisher et al., 2006). These extents do not appear to have changed markedly since the early 1970s based on an assessment of 1973 Landsat MSS imagery — but, with pixel sizes of approximately 0.5 ha as opposed to Landsat TM imagery (pixel size of 0.09 ha) consulted by Fisher et al. (2006) for their land cover assessment, and steep terrain, an accurate measure of forest extent change is problematic (Rohan Fisher, personal communication). Nonetheless, FGD interviews elicited information that (a) in living memory, a number of important forested areas have been depleted or vanished as a result of felling, burning, and cultivation activities, and (b) that certain forest resources are now very scarce or unavailable (ACIAR, 2004a,b). In general, however, it would appear that at both sites limited forest extent has been prevalent for many decades at least.

For the forest resource inventory, 40 plots were established at Lukuwinggir, and 36 at Doromeli, of which 21 and 10 plots, respectively, were selected by the local community (Table VI). Comparison of forest vegetation structural attributes between randomly and community selected plots indicates that (1) at Lukuwinggir, the community selected plots tended to comprise larger stem sizes, but which otherwise contained similar proportions of Priority species, and (2) at Dorameli, all structural attributes were markedly similar (Table VI). It follows that, for the purposes of this analysis, assembled data may be considered representative generally of the natural distributions and abundances of Priority species at each locale. 
Hum Ecol (2007) 35:345-359

353

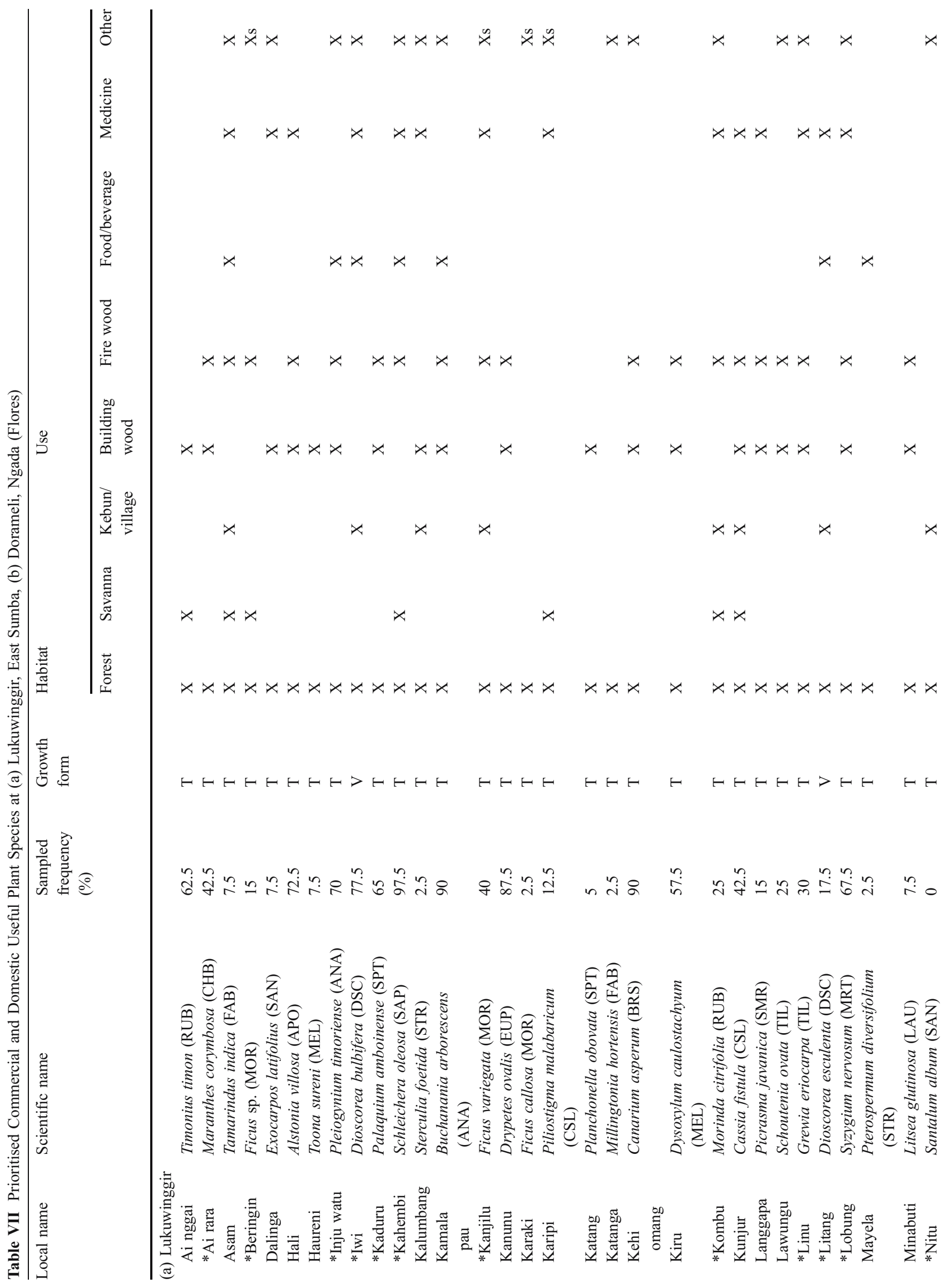

包 Springer 


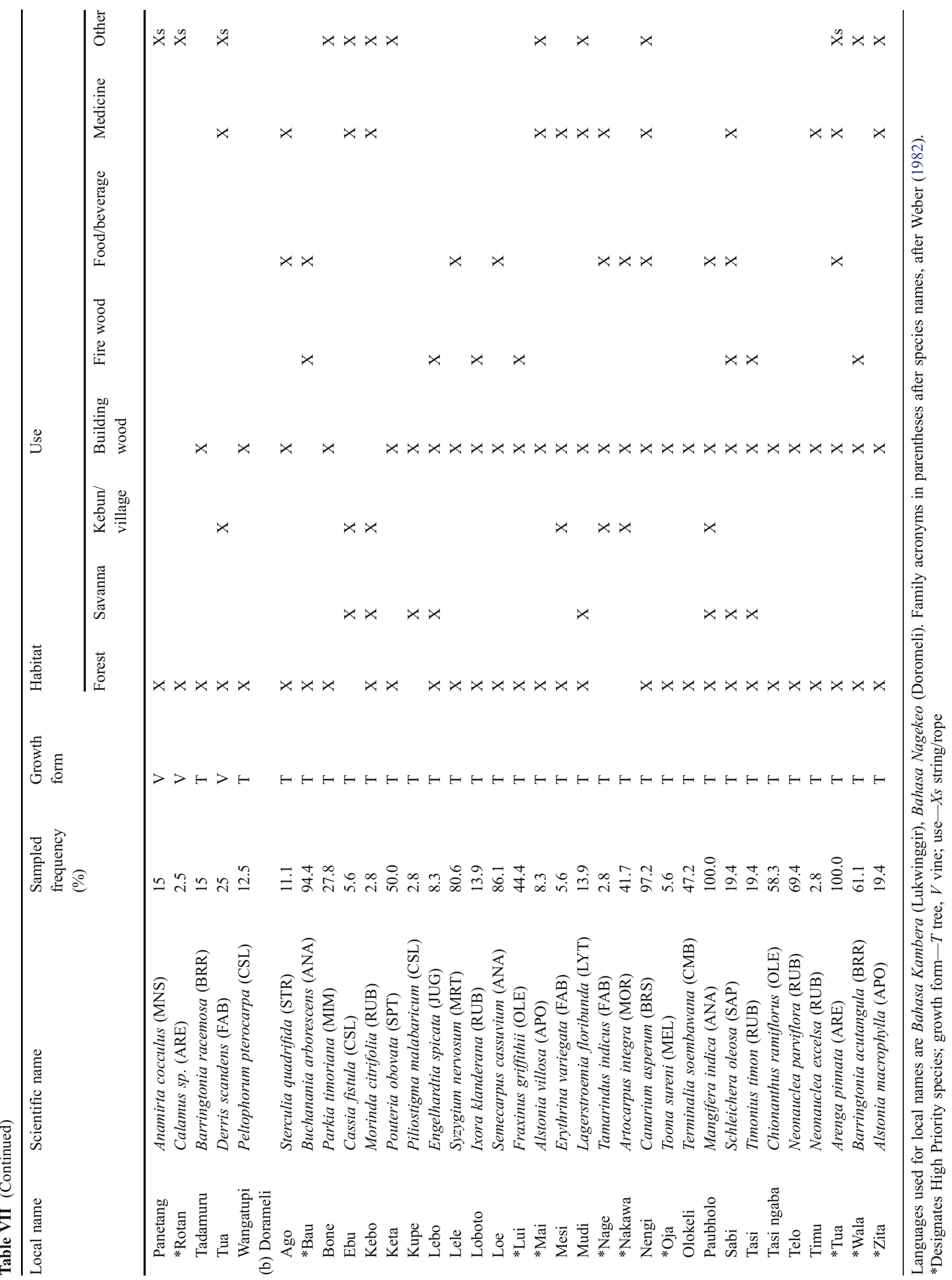


The sampled frequencies of occurrence of Priority species and their usages and habitat relations as given by community participants themselves, are given in Table VII. Strikingly, both at Lukuwinggir and Dorameli the great majority of Priority species are (1) understood to occur in forest habitats, with a few species restricted to either savannas and/or kebun, and (2) comprise trees used mainly for construction (including housing, furniture, implements), and to lesser extents firewood, and a variety of other purposes. Notably, (1) edible yams (Dioscorea spp.) were included as High Priority species at Lukuwinggir, consistent both with their importance as seasonal staples and with one of the stated reasons for prescribed burning at this village (Table V), and (2) construction bamboo, while relatively uncommon at both villages, was not prioritized (despite prompting for its inclusion). Bamboo is, however, an important economic commodity at Kiritana (Table III).

Population size estimates of High Priority species are given in Table VIII. Given that populations of 10,000 individuals require mean densities of at least 11.5 individuals $\mathrm{ha}^{-1}$ at Lukuwinggir, and $15.8 \mathrm{ha}^{-1}$ at Dorameli, it is apparent that very substantial resources of larger stemmed trees $(>10 \mathrm{~cm}$ DBH) exist for a few species (e.g., Lukuwinggir—Schleichera oleosa, Ficus variegata; Dorameli-Buchanania arborescens, Fraxinus griffithii, Arenga pinnata), and not others - especially Santalum album (Sandalwood), Calamus sp. (Rotan) at Lukuwinggir, and Alstonia villosa, Toona sureni at Dorameli. Whilst evidently rare in forest habitats, larger adult populations of Tamarindus indica (Dorameli) and Morinda citrifolia
Table VIII Population Size Estimate $( \pm$ S.E.M.) of High Priority Species at (a) Lukuwinggir, (b) Dorameli

\begin{tabular}{|c|c|c|c|c|c|}
\hline \multirow[t]{2}{*}{$\begin{array}{l}\text { Local } \\
\text { name }\end{array}$} & \multirow[t]{2}{*}{ Scientific name } & \multirow[t]{2}{*}{ Sampled frequency $(\%)$} & \multicolumn{3}{|c|}{$\begin{array}{l}\text { Population size estimate } \\
\text { (no. individuals / ha) }\end{array}$} \\
\hline & & & $<2 \mathrm{~m}$ tall & $\begin{array}{l}2 \mathrm{~m}- \\
10 \mathrm{~cm} \\
\mathrm{DBH}\end{array}$ & $\begin{array}{l}>10 \mathrm{~cm} \\
\mathrm{DBH}\end{array}$ \\
\hline
\end{tabular}

(a) Lukuwinggir

\begin{tabular}{|c|c|c|c|c|c|}
\hline \\
\hline Ai rara & Maranthes corymbosa & 42.5 & $10 \pm 4.1$ & $7.5 \pm 2.9$ & $2.5 \pm 1$ \\
\hline Beringin & Ficus sp. & 15 & $0.3 \pm 0.3$ & $0 \pm 0$ & $4.5 \pm 1.7$ \\
\hline Inju & Pleiogynium & 70 & $32.3 \pm 8.9$ & $10.8 \pm$ & $4 \pm 1.4$ \\
\hline watu & timoriense & & & 2.2 & \\
\hline Iwi & Dioscorea bulbifera & 77.5 & $424 \pm 105.2$ & $5.5 \pm 4.2$ & n.a. \\
\hline Kaduru & $\begin{array}{l}\text { Palaquium } \\
\text { amboinense }\end{array}$ & 65 & $140.5 \pm 35.3$ & $36 \pm 9.7$ & $9 \pm 2.8$ \\
\hline Kahembi & Schleichera oleosa & 97.5 & $259 \pm 45.2$ & $74 \pm 12.9$ & $\begin{array}{c}118.5 \pm \\
17.8\end{array}$ \\
\hline Kanjilu & Ficus variegata & 40 & $1.3 \pm 0.6$ & $3.5 \pm 1.5$ & $14 \pm 5.7$ \\
\hline Kombu & Morinda citrifolia & 25 & $1.8 \pm 0.7$ & $2 \pm 1$ & $0.5 \pm 0.3$ \\
\hline Linu & Grewia eriocarpa & 30 & $1.5 \pm 0.7$ & $1.5 \pm 0.8$ & $2 \pm 0.4$ \\
\hline Litang & Dioscorea esculenta & 17.5 & $\begin{array}{c}201.5 \pm \\
118.3\end{array}$ & $0 \pm 0$ & n.a. \\
\hline Lobung & Syzygium nervosum & 67.5 & $98 \pm 43.3$ & $\begin{array}{l}17.8 \pm \\
7.1\end{array}$ & $8.3 \pm 2.2$ \\
\hline Nitu & Santalum album & 0 & - & - & - \\
\hline $\begin{array}{l}\text { Rotan } \\
\text { Dorameli }\end{array}$ & Calamus sp. & 2.5 & $4.8 \pm 0$ & $0 \pm 0$ & n.a. \\
\hline $\mathrm{Bau}$ & $\begin{array}{c}\text { Buchanania } \\
\text { arborescens }\end{array}$ & 94.4 & $157.5 \pm 25.9$ & $30 \pm 9.7$ & $\begin{array}{c}25.3 \pm \\
16.6\end{array}$ \\
\hline Lui & Fraxinus griffithii & 44.4 & $30.3 \pm 11.8$ & $8.1 \pm 6.6$ & $\begin{array}{c}10.6 \pm \\
16.8\end{array}$ \\
\hline Mai & Alstonia villosa & 8.3 & $0.8 \pm 0.5$ & $0 \pm 0$ & $0.6 \pm 0$ \\
\hline Nage & Tamarindus indicus & 2.8 & $0 \pm 0$ & $0.3 \pm 0$ & $0 \pm 0$ \\
\hline Nakawa & Artocarpus integra & 41.7 & $27.2 \pm 7.8$ & $0.6 \pm 0.6$ & $3.9 \pm 12.5$ \\
\hline Oja & Toona sureni & 5.6 & $2.2 \pm 2.2$ & $1.1 \pm 0.4$ & $1.1 \pm 1.1$ \\
\hline Tua & Arenga pinnata & 100.0 & $\begin{array}{l}733.6 \pm \\
104.8\end{array}$ & $\begin{array}{c}176.1 \pm \\
22.5\end{array}$ & $\begin{array}{l}155 \pm \\
44.1\end{array}$ \\
\hline Wala & $\begin{array}{c}\text { Barringtonia } \\
\text { acutangula }\end{array}$ & 61.1 & $34.4 \pm 9.7$ & $4.4 \pm 2.7$ & $2.5 \pm 5.3$ \\
\hline Zita & Alstonia macrophylla & 19.4 & $0.6 \pm 0.4$ & $0 \pm 0$ & $3.3 \pm 0$ \\
\hline
\end{tabular}


(Lukuwinggir) presumably occur more commonly in kebun given their domestic importance.

\section{Discussion}

Livelihoods and Resources

Village communities occupying predominantly savanna landscapes in eastern Sumba and central Flores are reliant on a range of mixed farming activities, with different livelihood emphases in different locations. Although savannas comprise the predominant land cover at all villages save Dorameli (Flores), their relative economic contribution is at best tertiary (at Lukuwinggir, Sumba); even where livestock provide the major livelihood source, the value of free-ranging cattle and horses is outweighed by more domesticated animals which are confined mostly to the kebun or kampung (village complex). Even if possible, investing more heavily in free-ranging livestock (as advocated by various international development agencies) would not necessarily provide increased economic benefits given the harsh, dry conditions particularly at the end of the dry season, associated lack of water, and the ever-present threat of fires. In late 2002, for example, thousands of cattle died in East Sumba as a result of the extended dry season, exacerbated by extensive fires. The capacity to expand Imperata grasslands for thatch production in these landscapes is limited similarly by the availability of suitable perennially moist sites.

Around $90 \%$ of cattle in Nusa Tenggara (combining the Provinces of Nusa Tenggara Timur and Nusa Tenggara Barat) are Bali cattle, Bos javanicus, a breed with recognized market acceptance in other parts of Indonesia, and the ability to thrive and achieve high conception rates under adverse nutritional and climatic conditions (Bamaulin, 2000; Bamaulin and Wirdahayati, 2003). Given that calving in Bali cattle occurs mostly in the dry season, enhanced calf survival and productivity realistically is reliant on the implementation of intensive management systems. In West Timor, such systems have been developed which involve (1) early weaning for calves born in the dry season, and (2) the use of communal pens, and associated feeding with grasses and mixed legumes. Such intensive systems can reduce the fattening period from 1.5-2 years to as little as 6 months (Bamaulin and Wirdahayati, 2003). As far as we are aware such intensive management has, as yet, not been implemented to any extent either in East Sumba or Ngada.

Small areas of forest provide important resources at all study villages, especially construction timber, fire wood, fibres, medicines, staple yams (in East Sumba), as well as other recognized, if less tangible, environmental amenities such as the protection of sumber air (headwater springs).
As noted previously, stocks of some High Priority forest products are already in critically short supply in both study locations; a situation that in the longer term could be addressed with enrichment or agro-forestry plantings. More promising from a commercial perspective is the substantial population resource base of other resources, especially kahembi (Schleichera oleosa) at Lukuwinggir, and tua (Arenga pinnata) at Dorameli.

Kahembi is the major host plant for a burrowing beetle larva, kutu lak (Laccifer lacca Kerr) which, in association with a fungus, produces a natural, highly valued, exported varnish, lak (or lacquer). Despite ultimately killing host trees, if carefully managed high quality kutu lak can be harvested from different limbs for many years. The potential for developing a significant regional industry has been explored by Juspan (2004); major issues are those of quality control and effective marketing. Mature kahembi occur in very large numbers in East Sumba, are very hardy, and, with effective fire management, can be readily grown in agro-forestry settings (Juspan, 2004). The potential for contributing to village livelihoods at Lukuwinggir is indicated by the observation that, whereas in 2002-2003 kutu lak contributed just $5 \%$ of GHP (Table III), by the time of the forest inventory in 2004 that proportion had increased to $36 \%$, increasing average GHP per capita in sampled households by a staggering 300\% (unpublished data).

Tua likewise grows naturally in large numbers at Dorameli and other relatively moist sites in Ngada, and has considerable economic value given that plant parts are used variously to make palm toddy (from sap), brooms (fibre, leaves), twine (fibre), roof thatching (leaves), and house poles (stems). Dorameli villagers indicate that tua is economically productive from 10-15 years of age, will continue to produce sap from the bases of inflorescences for a further 15-20 years, and that stems are useful for house poles at around 25-30 years. Presumably, greater economic returns could be made from tua with targeted product development and marketing.

In sum, it does not follow, just because grassland savannas in eastern Sumba and central Flores are the predominant land cover and by default the most extensive landuse, that contemporary savanna-based livelihood options are necessarily the most economically fruitful (cf. Dove, 2004; Tacconi and Ruchiat, 2006). Rather, it is selfevident that, into the future, an integrated range of enterprise options, including agro-forestry and other perennial crops, domesticated or more intensively managed kebun- or kampung-based livestock, and home industries (e.g., weaving, furniture making), are likely to be more profitable in these seasonal environmental settings. While the observations of Dove (2004) doubtless are pertinent to more humid parts of Indonesia and other parts of Asia, where economically important anthropogenic grasslands 
and derived products may be in short supply, it is clearly not the case that such arguments can be extended to strongly seasonal savannas, and where production over the greater part of the landscape is significantly limited by water availability and attendant fire management issues.

Fire Management and the Resource Base

Rationales for kebun- and landscape-scale fire management are clearly articulated by village communities in East Sumba and Ngada (Table V); however, contemporary practice is typically another matter. The testimony of villagers, along with supporting evidence from remote sensing studies (i.e., extensive fires that have burnt from surrounding villages into and through kebun areas; Fisher et al., 2006), indicates that fire today is often used carelessly and wantonly with little regard for where fires may end up, whether they are started for preparing kebun, pasture management, hunting, accidentally, or maliciously. Over the 3 year study period numerous examples were observed by project staff where uncontrolled landscape fires destroyed buildings, crops, and inflicted needless damage on forest resources-e.g., killing mature trees on forest margins, and thereby further promoting incursions of flammable grasses and weeds (e.g., Chromalaena odorata). In 2002, most of the kebun at Dhereisa (Flores) were burnt from an uncontrolled hunting fire and, were it not for the enterprise of women through their weaving, significant hardship, including starvation, would have ensued.

The lack of fire management planning and coordination evidenced at all study villages is all the more surprising given the very tangible benefits including economically, which would accrue, if this were undertaken. For example, if, instead of burning all hillsides around kampung and kebun areas, some steep slopes were left unburnt (leaving more accessible slopes for grazing) to promote regeneration of stocks of hardy woody plants (still existing, albeit as firesuppressed suckers among the grasses), then communities would have easy access to firewood; a sore point for women in some kampung who frequently have to travel long distances to obtain supplies. Indeed, a significant component of project activities has been to undertake integrated agro-forestry and associated fire management activities in all four villages to demonstrate such practical benefits.

The underlying causes of the breakdown in customary fire management practices recorded here through discussions with community members, and as documented for other parts of NTT where, customarily, villagers would (and in places still do) undertake coordinated fire management mostly for a range of agricultural purposes (Fox, 1977; Ataupah, 2000; Therik, 2000), are manifold; here we consider three relevant issues.
First, within the cultural domain it is important to appreciate that (1) local clan structures/social stratification and land ownership systems may differ markedly from village cluster to village cluster, and (2) as indicated previously, very significant societal change has been occurring in recent decades, most notably the replacement of traditional hierarchical social structures with more classless forms. Conflicts over land ownership both within and between village communities are common, manifested in open disagreements over use and management of resources, with one result being that no fire management may be undertaken on contested lands, and/or that fire is used actively as a weapon of disputation. Examples of social conflicts over land and resultant fire problems were evident at all our study locations. Such conflicts are only exacerbated by increasing population pressures, currently running at around $2 \%$ p.a. (Biro Pusat Statistik, 2002), given finite arable and forested land resources.

Second, within the political domain, a major issue impacting directly on community livelihoods concerns land tenure conflicts, and attendant issues concerning access to, and utilization of resources, between local communities and regulatory authorities, especially the Dinas Kehutanan (Provincial and District Offices of the Dept. Forestry). Dinas Kehutanan directly administers around $30 \%$ of NTT (including significant areas of unforested land). Major conflicts over land often result in the burning of designated forestry lands and plantations by disaffected communities as an assertion of traditional rights in land (McWilliam, 2000). Dennis et al. (2005) describe underlying land tenure conflicts as a major factor contributing to destructive fire activities in western Indonesia.

And third, also in the political domain, current NTT Provincial Government policy "proscribes all cultural burning in a wholly futile attempt to curb the practice. This policy position derives in large degree from national perspectives and guidelines, but its origins can also be identified in historical Dutch Colonial proscriptions against any local use of fire in land management and clearing" (McWilliam, 2000, p. 81). Addressing the broader national policy agenda, Tacconi and Ruchiat (2006) state the issue equally bluntly, "the current zero burning policy does not address regional management needs, is unenforced, and is unenforceable." The practical effects of this policy on peoples' livelihoods are felt throughout Indonesia (Tacconi, 2003; Dennis et al., 2005), but especially so in semiarid regions where the use of fire continues to be an intrinsic component of farming systems. Similar recent experience in west African savannas, where attempts have been made in various countries to proscribe burning, has also proven to be counterproductive (Laris, 2002). A major outcome of the present project has been growing recognition by key local government departments (BAPPEDA-the regional 
planning board; Dinas Kehutanan) of the utility of, and the need to provide support for, community-based fire management.

More broadly, however, the above social and political factors, combined with the natural propensity of regional savanna landscapes to increasingly carry fire as the dry season progresses, conspire to significantly impact on environmental assets, livelihood resources, and thereby economic conditions. Given these factors, it is axiomatic that, without effective fire management and a supportive policy environment, sustainable livelihoods development will continue to be elusive in savanna landscapes of eastern Indonesia.

Acknowledgments Many people have contributed to the assembly of data presented here, but especially Umbu Sawola, Paulina Hada Indah, Agus Rawambaku (Tim Sumba); Fransiska Rengo, Justinus Depa, Wilfrida E. Boba Ruba (Tim Ngada); Andrew Edwards, Rohan Fisher, Greg Hill, Bronwyn Myers (Tim Darwin); Dorameli, Dhereisa, Lukuwinggir and Kiritana communities; Petrus Kesu (BAPPEDA, Ngada), Ben Polomaing (Dinas Kehutanan, Ngada), Umbu Tamu Kalaway (BAPPEDA, Sumba Timur), Juspan (Dinas Kehutanan, Sumba Timur); staff of the Herbarium Bogoriense, Bogor. The research was funded principally by the Australian Centre for International Agricultural Research (ACIAR), the Crawford Foundation (Australia), and the Tropical Savannas Management Cooperative Research Centre, Darwin.

\section{References}

ACIAR, (2004a). Preliminary Rural Appraisal for East Sumba Study Area, Australian Centre for International Agricultural Research (ACIAR), Canberra, Australia.

ACIAR, (2004b). Preliminary Rural Appraisal for Ngada Study Area, Australian Centre for International Agricultural Research, Canberra, Australia.

Ataupah, H. (2000). Fire, traditional knowledge, and cultural perspectives in Nusa Tenggara Timur. In Russell-Smith, J., Hill, G. J. E., Djoeroemana, S., and Myers, B. A. (eds.), Fire and Sustainable Agricultural and Forestry Development in Indonesia and northern Australia, ACIAR, Canberra, Australia, pp. 73-76.

Bamaulin, A. (2000). Livestock production and fire management in East Nusa Tenggara. In Russell-Smith, J., Hill, G. J. E., Djoeroemana, S., and Myers, B. A. (eds.), Fire and Sustainable Agricultural and Forestry Development in Indonesia and northern Australia, ACIAR, Canberra, Australia, pp. 69-72.

Bamaulin, A., and Wirdahayati, R. B. (2003). Nutrition and management strategies to improve Bali cattle productivity in Nusa Tenggara. In Entwhistle, K. and Lindsay, D. R. (eds.), Strategies to Improve Bali Cattle in Eastern Indonesia, ACIAR, Canberra, Australia, pp. 17-22.

Barlow, C., Gondowarsito, R., Birowo, A. T., and Jayasuriya, S. K. W. (1990). Development in Eastern Indonesia: The Case of Nusa Tenggara Timur, International Issues no. 13, Australian International Development Assistance Bureau, Canberra, Australia.

Biro Pusat Statistik, (2002). Nusa Tenggara Timur Dalam Angka, Biro Pusat Statistik, Kupang, Indonesia.
Biro Pusat Statistik, (2003a). Sumba Timur Dalam Angka, 2002, Biro Pusat Statistik, Kupang, Indonesia.

Biro Pusat Statistik, (2003b). Ngada Dalam Angka, 2002, Biro Pusat Statistik, Kupang, Indonesia.

Biro Pusat Statistik, (2003c). Kecamatan Pandawai Dalam Angka, 2002, Biro Pusat Statistik, Kupang, Indonesia.

Biro Pusat Statistik, (2003d). Kecamatan Boawae Dalam Angka, 2002, Biro Pusat Statistik, Kupang, Indonesia.

Biro Pusat Statistik, (2004). Indonesia Dalam Angka, 2000-2003, Biro Pusat Statistik, Jakarta, Indonesia.

Colfer, C. J. P. (2002). Ten propositions to explain Kalimantan's fires. In Colfer, C. J. P., and Resosudarmo, I. A. P., (eds.), Which Way Forward? People, Forests and Policymaking in Indonesia, Resources for the Future, Washington, District of Columbia, pp. 309-324.

Cunningham, A. B. (2002). Applied Ethnobotany: People, Wild Plant Use \& Conservation, Earthscan, London.

Dennis, R. (1999). A Review of Fire Projects in Indonesia, 1982 1998, CIFOR, ICRAF, UNESCO, European Commission, Bogor, Indonesia.

Dennis, R. A., Mayer, J., Applegate, G. B., Chokkalingam, U., Colfer, C. J. P., Kurniawan, I., Lachowski, H., Maus, P., Permana, R. P., Ruchiat, Y., Stolle, F., Suyanto, S., and Tomich, T. (2005). Fire, People and Pixels: Linking Social Science and Remote Sensing To Understand Underlying Causes and Impacts of Fires in Indonesia. Human Ecology 33: 465-504.

Djoeroemana, S., Semangun, H., Saragih, B., and Sulthoni, A. (2000). The implications of fire management and restoration for economic development in East Nusa Tenggara. In Russell-Smith, J., Hill, G. J. E., Djoeroemana, S., and Myers, B. A., (eds.), Fire and Sustainable Agricultural and Forestry Development in Indonesia and northern Australia, ACIAR, Canberra, Australia, pp. 52-55.

Dove, M. R. (2004). Anthropogenic Grasslands in Southeast Asia: Sociology of Knowledge and Implications for Agroforestry. Agroforestry Systems 61: 423-435.

Fisher, R., Bobalinda, E. W., Rawambaku, A., Hill, G. J. E., and Russell-Smith, J. (2006). Remote sensing of fire regimes in semiarid Nusa Tenggara Timur, eastern Indonesia: patterns and prospects. International Journal of Wildland Fire 15: 307-317.

Fox, J. J. (1977). The Harvest of the Palm: Ecological Change in Eastern Indonesia, Harvard University Press, Cambridge, New York.

Gadas, S. L. (2000). Forest land and fire management in East Nusa Tenggara. In Russell-Smith, J., Hill, G. J. E., Djoeroemana, S., and Myers, B. A. (eds.), Fire and Sustainable Agricultural and Forestry Development in Indonesia and northern Australia, ACIAR, Canberra, Australia, pp. 62-64.

Juspan (2004) Budidaya Kutu Lak (Laccifer lacca Kerr): Produksi, pemasaran, dan kontribusi pada pendapatan petani, M.S. thesis, Universitas Kristen Satya Wacana, Salatiga, Indonesia

Kurniawan, I., and Tacconi, L. (2005). Indonesia's Vegetation Cover: 2002, CIFOR, Bogor, Indonesia (CD-ROM version).

Laris, P. (2002). Burning the Seasonal Mosaic: Preventative Burning Strategies in the Wooded Savanna of Southern Mali. Human Ecology 30(2): 155-186.

McWilliam, A. (2000). Fire and cultural burning in Nusa tenggara Timur: Some implications of fire management practices for Indonesian Government Policy. In RussellSmith, J., Hill, G. J. E., Djoeroemana, S., and Myers, B. A. (eds.), Fire and Sustainable Agricultural and Forestry Development in Indonesia and northern Australia, ACIAR, Canberra, Australia, pp. 80-85.

Monk, K. A., De Fretes, Y., and Reksodiharjo, L. G. (1997). The Ecology of Nusa Tenggara and Maluku, Periplus Editions, Singapore. 
Mudita, W. (2000). Fire and the management of agricultural systems in East Nusa Tenggara. In Russell-Smith, J., Hill, G. J. E., Djoeroemana, S., and Myers, B. A. (eds.), Fire and Sustainable Agricultural and Forestry Development in Indonesia and northern Australia, ACIAR, Canberra, Australia, pp. 56-61.

Mudiyarso, D., Lebel, L., Gintings, A. N., Tampubolon, S. M. H., Heil, A., and Wasson, M. (2004). Policy Responses to Complex Environmental Problems: Policy Activity on Transboundary Haze from Vegetation Fires in Southeast Asia. Agriculture, Ecosystems and Environment 104: 47-56.

Page, S. E., Siegert, F., Rieley, J. O., Boehm, H-D. V., Adi, Jaya and Suwido, Limin. (2002). The Amount of Carbon Released from Peat and Forest Fires in Indonesia in 1997. Nature 420: 61-65.
Tacconi, L. (2003). Fires in Indonesia: causes, costs and policy implications, Occasional Paper no. 38. CIFOR, Bogor, Indonesia. Tacconi, L., and Ruchiat, Y. (2006). Livelihoods, Fire, and Policy in Eastern Indonesia. Singapore Journal of Geography 27: 6781.

Therik, T. (2000). The role of fire in swidden cultivation: a Timor case study. In Russell-Smith, J., Hill, G. J. E., Djoeroemana, S., and Myers, B. A. (eds.), Fire and Sustainable Agricultural and Forestry Development in Indonesia and northern Australia, ACIAR, Canberra, Australia, pp. 77-79.

Weber, W. A. (1982). Mnemonic Three-Letter Acronyms for the Families of Vascular Plants: A Device for More Effective Herbarium Curation. Taxon 31: 74-88. 